\section{Rapid Preparation of Neurospora Mitochondria}

Preparation of mitochondria from Neurospora usually requires quite drastic treatments such as micro-mills, glass beads, sand and disruption of protoplasts. It also requires from 2 to $12 \mathrm{~h}$ after collection to isolate the mitochondrial fraction. We have developed a method for preparing mitochondria in $30 \mathrm{~min}$ using a combination of three new techniques-a nylon bag, a glass homogenizer and rapid centrifugation.

Neurospora, wild type strain $Y 74 A$ (Genetics Institute, Copenhagen), was grown from conidia on Vogel's complete medium as described by Hall and Greenawalt ${ }^{1,2}$. Conidia from a slant grown at room temperature for 1-2 weeks were inoculated in $10 \mathrm{ml}$. of water into $500 \mathrm{ml}$. of Vogel's medium in a 2 l. Erlenmeyer flask. Growth was for $14-16 \mathrm{~h}$ at $30^{\circ} \mathrm{C}$ on an orbital incubator at about 200 r.p.m. (ref. 2).

Working at $4^{\circ} \mathrm{C}$ the hyphal mat was collected by pouring the contents of the flask through a nylon bag (double layer, mesh about $50 / \mathrm{cm}^{3}$ ) and resuspending it in 200 ml. of $0.6 \mathrm{M}$ sorbitol. Scissors were then used to break up the hyphal mat which was poured through the nylon bag again, and then resuspended in $200 \mathrm{ml}$. of a preparation medium consisting of $0.25 \mathrm{M}$ sucrose, $0.005 \mathrm{M}$ EDTA and $0 \cdot 3$ per cent crystalline bovine serum albumin. The hyphae were then homogenized in two batches in a fairly loose-fitting, medium-coarse, ground glass Wicklund homogenizer $(130 \mathrm{ml}$. volume of ground glass stem and $230 \mathrm{ml}$. total volume; Wicklund Glasinstrument, Idungatan 7, Stockholm, Va.). A total of five-six strokes were needed to break the hyphae and obtain an even suspen. sion. The suspension was poured through the nylon bag to remove whole cells, cell walls, etc., and it was then centrifuged at $10,000 \mathrm{~g}$ for $5 \mathrm{~min}$.

The precipitate containing the mitochondria was gently resuspended in $100 \mathrm{ml}$, of preparation medium using a Ten-Broek ground glass homogenizer (A. H. Thomas and Co., Philadelphia). Further centrifugation at $10,000 \mathrm{~g}$ for $5 \mathrm{~min}$ and resuspension of the precipitate in about $3 \mathrm{ml}$. of preparation medium (without EDTA) gave a mitochondrial fraction containing about $20 \mathrm{mg}$ of protein/ $\mathrm{ml}$. The addition of a short $(1 \mathrm{~min}) 2,000 \mathrm{~g}$ centrifugation and/or the elimination of the second $10,000 \mathrm{~g}$ centrifugation may be used to give cleaner and/or faster preparations.

These mitochondria exhibit oxidative phosphorylation, respiratory control, reversed electron transport, ATPase and pyrophosphatase activities. This work was supported by the Swedish Natural Science Research Council.

Department of Botany,

$$
\text { D. O. HALL }
$$

King's College, London.

Botanical Institute,

University of Stoekholm,

Sweden.

Received June 25, 1968.

${ }^{1}$ Hall, D. O., and Greenawalt, J. W., Biochem. Biophys. Res, Commun., 17, 565 (1964).

${ }^{2}$ Hall, D. O., and Greenawalt, J. W., J. Gen. Microbiol., 48, 419 (1967).

${ }^{3}$ Nobel, P. S., Plant Physiol., 42, 1389 (1967).

\section{Experimental Human B Influenza Virus Infection in Chincoteague Ponies}

A RECENT serological survey conducted among a population of horses in an area near Toronto, Canada, showed a high frequency of antibody to Myxovirus influenzae type $B$ (ref. 1). Although only a limited number of horses was tested, the evidence nevertheless suggests that natural infection of equines does occur. In order to study the susceptibility of horses to type $B$ influenza virus, equines were inoculated with a virus strain recovered from a human source.

Experiments were conducted with twelve ponies of both sexes (Equus caballus) from a wild herd living on Assateague Island, Virginia. The animals had previously been relatively isolated from human beings, had no known prior contact with other equine animals and lacked detectable serum neutralizing antibody $(<1: 2)$ to the challenge virus. The approximate age of the ponies used in the study was $1 \cdot 5-2 \cdot 0 \mathrm{yr}$. The ponies were inoculated in a closed shed that was sectioned into open stalls. The virus strain $(B /$ Mass/3/66) used in the experiments was provided by $\mathrm{Dr}$ J. A. Morris, Division of Biologies Standards, US National Institutes of Health. Viral inocula were prepared and tested for other microbiological agents by previously described procedures ${ }^{2,3}$. The material administered to ponies 1-9 (Table 1 ) was the ninth passage in rhesus monkey kidney cultures (RHMK). These animals received $10 \mathrm{ml}$. of undiluted inoculum containing $10^{7.0} T C I D_{50}$ of type $B$ influenza virus; $5 \mathrm{ml}$. was nebulized and sprayed into the nasal cavities and $5 \mathrm{ml}$. was administered intratracheally by a needle ${ }^{4}$.

Table 1. INFECTION RESPONSES OF HORSES FOLLOWING INOCULATION WITH TYPE $B$ HUMAN INFLUENZA VIRUS

\begin{tabular}{|c|c|c|c|c|c|c|}
\hline \multirow{3}{*}{$\begin{array}{l}\text { Pony } \\
\text { No. }\end{array}$} & \multirow{3}{*}{$\begin{array}{l}\text { Adminis- } \\
\text { tered } \\
\text { dose } \\
\left(T C I D_{50}\right)\end{array}$} & \multicolumn{2}{|c|}{ Fever } & \multirow{3}{*}{$\begin{array}{l}\text { Virus } \\
\text { isolation, } \\
\text { No. of } \\
\text { days }\end{array}$} & \multirow{2}{*}{\multicolumn{2}{|c|}{$\underset{\text { titre }}{\text { Neutralizing antibody }}$}} \\
\hline & & \multirow{2}{*}{$\begin{array}{c}\text { Maximum } \\
\text { recorded } \\
\text { tempera- } \\
\text { ture }\left({ }^{\circ} \mathrm{F}\right)\end{array}$} & \multirow{2}{*}{$\begin{array}{l}\text { No. of days } \\
\text { of tem- } \\
\text { perature } \\
\geqslant 102 \cdot 5\end{array}$} & & & \\
\hline & & & & & Serum & $\begin{array}{l}\text { Nasal } \\
\text { secretion }\end{array}$ \\
\hline 1 & $10^{7.0}$ & 101.8 & 0 & 2 & $<2 \dagger$ & 2 \\
\hline 2 & $10^{7.0}$ & 10 & 0 & 0 & 8 & \\
\hline$\overline{3}$ & $10^{7.0}$ & $105 \cdot 0$ & 1 & 6 & 8 & 4 \\
\hline 4 & $10^{7.0}$ & $102 \cdot 0$ & 0 & 2 & $\geqslant 1 \theta$ & 2 \\
\hline 5 & $10^{7.0}$ & $102 \cdot 0$ & 0 & I & 64 & 4 \\
\hline 6 & $10^{7.0}$ & $101 \cdot 6$ & 0 & 6 & 8 & 2 \\
\hline 7 & $10^{7.0}$ & $101 \cdot 8$ & 0 & 0 & $\geqslant 16$ & $<2$ \\
\hline 8 & $10^{7.0}$ & $102 \cdot 0$ & 0 & 5 & 2 & $<2$ \\
\hline 9 & $10^{7.0}$ & $103 \cdot 8$ & 2 & 4 & 8 & $<2$ \\
\hline 10 & $10^{3.8}$ & $105 \cdot 0$ & 3 & 0 & $<2$ & $<2$ \\
\hline 11 & $10^{2.8}$ & 103.6 & 1 & 2 & 8 & $<2$ \\
\hline 12 & 0 & $102 \cdot 0$ & 0 & 0 & $<2$ & $<\overline{2}$ \\
\hline
\end{tabular}

* Titre on the twenty-eighth day after inoculation; all pre-inoculation

specimens were $<1: 2$.
+ Expressed as the reciprocal of the dilution.

In an experiment to determine the feasibility and effects of inoculating ponies with nasal washings from an inoculated animal, a specimen collected from pony 9 on day 2 and day 3 was used as an inoculum for ponies 10 and 11 respectively. These two horses had been kept completely separated from the inoculated animals until the day of virus challenge. The material was delivered nasopharyngeally to each pony by nebulization and, based on infectivity titrations with RHMK cultures, the total administered dose of virus for pony 10 was $10^{3.9} T C I D_{50}$ and for pony 11 was $10^{2.9} T C I D_{50}$. The communicability of the infection was studied by placing an animal (pony 12) which lacked serum neutralizing antibody to the inoculum virus strain in the same stall with pony 9 eight hours after the latter had been inoculated.

Rectal temperatures were taken twice daily for 7 days before inoculation and four times daily for 10 days after inoculation.

Veal infusion broth $(10 \mathrm{ml}$.) with 0.5 per cent bovine serum albumin and antibiotics was used to collect nasal wash specimens for virus isolation studies. Specimens were taken before inoculation, $6 \mathrm{~h}$ after inoculation and daily thereafter for 11 days. Immediately after collection, undiluted specimens were inoculated into RHMK cultures and embryonated eggs. Each virus isolate was identified by neutralization tests with appropriate antiserum.

Antibody titres of serum spocimens taken before and 28 days after inoculation were tested against 32 TCID $D_{30}$ of the tissue culture inoculum virus pool by the haem. adsorption-inhibition neutralization test in RHMK cultures. The same procedure was used to determine 